Renaissance Posthumanism 
This page intentionally left blank 


\section{Renaissance Posthumanism}

Joseph Campana and Scott Maisano

Editors

F O R D A M N IVERS ITY PRES S

N E W Y R K 2 O I 6 
Copyright () 2016 Fordham University Press

All rights reserved. No part of this publication may be reproduced, stored in a retrieval system, or transmitted in any form or by any means-electronic, mechanical, photocopy, recording, or any other-except for brief quotations in printed reviews, without the prior permission of the publisher.

Fordham University Press has no responsibility for the persistence or accuracy of URLs for external or third-party Internet websites referred to in this publication and does not guarantee that any content on such websites is, or will remain, accurate or appropriate.

Fordham University Press also publishes its books in a variety of electronic formats. Some content that appears in print may not be available in electronic books.

Visit us online at www.fordhampress.com.

Library of Congress Cataloging-in-Publication Data available online at catalog.loc.gov.

Printed in the United States of America

$\begin{array}{llllllll}\text { I8 } & \text { I7 } & \text { I6 } & 5 & 4 & 3 & 2 & \text { I }\end{array}$

First edition 